\title{
СЛІДЧІ (РОЗНУКОВІ) ДІЇ ПОЧАТКОВОГО ЕТАПУ РОЗСЛІДУВАННЯ ЗЛОЧИНІВ, ВЧИНЕНИХ У СКЛАДІ ОРГАНІЗОВАНОї ГРУПИ
}

\author{
КИСЬКО Артем Іванович - здобувач Донецького юридичного інституту \\ МВС України
}

DOI:10.32782/NP.2019.4.16

УДК 343.98

В статье обосновъивается целесообразность проведения тактических операций для получения широкого круга доказательств на первоначальном этапе расследования. Предпринята попьттка вълделить особенности проведения первоочередньих следственных (розвискнъих) мероприятий и установить их содержание, $c$ учетом специфических признаков преступньхх группировок. На основании этих особенностей предложенъ рекомендащии расследования преступлений, совершенньх в составе организованной группь на начальном этапе, направленнье на повыпение эббективности уголовно-процессуального доказввания.

Ключевъе слова: организованная группа, досудебное расследование, первоначальнъий этап, тактика, следственнъие (розъикнъие) действия.

\section{Постановка проблеми}

Реформування політичного й економічного життя в Україні потребує невідкладного вирішення низки завдань, спрямованих як на активізацію євроінтеграційних процесів, що неможливо без забезпечення національної безпеки нашої держави. У зв'язку з цим, проблема протидії організованій злочинності, яка справляє руйнівний вплив на подальший розвиток демократичних інститутів, набуває більшої актуальності.

Незважаючи на активізацію наукових досліджень організованої злочинності, в сучасних умовах досі залишаються дискусійними питання, пов'язані із провадженням першочергових слідчих (розшукових) та негласних слідчих (розшукових) дій у перебігу досудо- вого розслідування кримінальних правопорушень, вчинених такими групами. Опитування правоохоронців показує, що на практиці нерідко нехтують криміналістичними особливостями таких угруповань, що призводить до зниження ефективності процесу доказування. Одночасно постає потреба удосконалення існуючих криміналістичних методик досудового розслідування злочинів, вчинених у складі організованої групи, з урахуванням їх специфічних ознак.

Аналіз останніх досліджень і публікацій

У юридичній літературі проблеми протидії організованій злочинності досліджувалися такими вченими, як Г. В. Андрусів, М. І. Бажанов, О. Я. Баєв, В. П. Бахін, Р. С. Бєлкін, Н. А. Гуторова, А. А. Коловоротний, І. В. Куртинов, В. М. Куц, В. С. Овчинський, Е. В. Трузян, О. Н. Ярмиш та інші. Завдяки теоретичним здобуткам вказаних науковців були з'ясовані різні підходи до тлумачення поняття організованої групи, а також встановлено концептуальний зміст їх специфічних ознак. Водночас, значно менша кількість праць присвячена особливостям досудового розслідування злочинів, вчинених у складі організованої групи, серед яких на увагу заслуговують дослідження В. М. Бикова, А. Ф. Гули, А. Я. Драпкіна, I. О. Жука, В. О. Коновалової, Д. А. Нескоромного, М. В. Проценка,В. Ю. Шепітька, які спрямували свою діяльність на вдосконалення криміналістичних методик розслідування даної категорії кри- 


\section{Кримінальне право, кримінальний процес та криміналістика}

мінальних проваджень. У той же час низка питань, зокрема пов'язаних з особливостями проведення початкових слідчих (розшукових) дій, залишаються дослідженими недостатньо, що обумовлює актуальність їх подальшої наукової розробки.

\section{Формування цілей статті}

Метою дослідження $є$ виокремлення та характеристика особливостей проведення окремих слідчих (розшукових) дій початкового етапу розслідування злочинів, вчинених у складі організованої групи.

\section{Виклад основного матеріалу}

Провадження слідчих (розшукових) дій у перебігу досудового розслідування злочинів, вчинених у складі організованої злочинної групи (далі - ОЗГ), має бути спрямовано на встановлення закріплених в ч.3 ст.28 КК України ознак такої групи: стійкості, попередньої зорганізованості, розподілі функцій і ролей, об’єднаності єдиним планом, відомим усім учасникам групи. Розслідування даної категорії кримінальних проваджень додатково ускладнюється багатьма факторами, які випливають із природи злочинних угруповань, зокрема: наявність декількох епізодів злочинної діяльності в межах одного кримінального провадження; наявність численних слідів різного характеру на місці злочину; широке коло висунутих криміналістичних версій; велика кількість співучасників, активна протидія розслідуванню з їх боку та ін..

Серед заходів початкового етапу розслідування таких злочинів найбільш дієвими визнаються: огляд місця події, речових доказів, допит свідків та очевидців з метою організації переслідування; одержання зразків для порівняльного дослідження; огляд одягу, взуття потерпілих, призначення криміналістичних експертиз (балістичної, судово-медичної експертизи ступеня тяжкості тілесних ушкоджень); вивчення характеру дій злочинців; проведення оперативних заходів щодо встановлення підозрюваних, місць їх перебування. 3 огляду на це, варто погодитись 3 думкою М. I. Панова, який стверджував, що за наявності будь-якої слідчої ситуації, особливо в умовах відсутності детальних відомостей про обставини злочину, вагому роль відігра- ють такі слідчі (розшукові) дії, як: огляд місця події, допити потерпілого та свідків [1, с. 108].

Водночас думка В. В. Топчія полягає в тому, що лише тактичні операції здатні з'ясувати більш широкий обсяг фактичних даних та у менший проміжок часу, аніж проведення відокремлених слідчих (розшукових) дій [2, с. 150]. Така позиція хоча і є дещо категоричною, але у багатьох випадках вважається виправданою. У такому плані система заходів у межах тактичної операції спрямовується на визначення первинних відомостей, необхідних для подальшого планування та висунення криміналістичних версій. До них відносяться: відомості про кримінальний досвід злочинців; відомості, що містяться у матеріалах оперативно-розшукових і кримінальних проваджень, де фігурували ці особ; відомості, що містяться у матеріалах кримінальних проваджень про аналогічні злочини. Тактична операція дозволяє покращити ефективність пізнавальної діяльності в перебігу розслідування злочинів, оскільки вона базується на системності оптимальних слідчих (розшукових) дій, негласних слідчих (розшукових) дій, які спрямовані на вирішення поставлених завдань розслідування.

Викриваючи організовану групу, яка вчинила певний злочин, на думку $\lambda$. Я. Драпкіна, доречно провести комплекс тактичних операцій, спрямованих на вирішення важливих проміжних завдань, які, у першу чергу, повинні деталізувати вихідну інформацію про конкретні кримінальні провадження. Серед таких тактичних операцій автор виділяє наступні: «затримання злочинців на місці злочину»; «затримання при контрольованій передачі від потерпілих грошей, цінностей»; «розшук і затримання злочинців за прикметами»; «виявлення корумпованих зв’ язків» [3, с. 341]. Аналогічної позиції дотримується М. П. Яблоков, вказуючи на важливість проведення таких тактичних операцій, як: припинення і попередження злочинних акцій, що почалися або готуються; затримання злочинців на місці злочину; розшук злочинців за ознаками зовнішності; викриття злочинців; прослуховування і запис телефонних та інших переговорів; виявлення корумпованих зв'язків; контрольовані операції з предметами, що перебувають у легальному й нелегальному обігу [4, с. 128]. 
Пов'язує тактичні операції із сутнісними ознаками організованої групи М. В. Проценко, серед яких, на його думку, основними є такі операції, як: розподіл функцій, стійкість групи, злочинна діяльність групи. Зокрема, ці тактичні операції реалізовуються завдяки проведенню огляду місця події, речей і документів, обшуків, допитів потеплілих та пі-дозрюваних, експертиз [5, с. 115]. Це, у свою чергу, вимагає деталізації тактики провадження слідчих (розшукових) дій.

У перебігу досудового розслідування особливої уваги потребує проведення огляду місця події, одним з головних завдань якого $\epsilon$ встановлення групового характеру вчинення злочину. Водночас не менш важливим залишаються питання виявлення слідів, 3'ясування механізму вчинення злочину, обстановки його здійснення. Таку ж позицію підтримує E. I. Макаренко, який визначив огляд місця події як невідкладну слідчу дією, що спрямована на дослідження території, де сталася подія, з метою виявлення та фіксування ознак злочину $[6$, c. 8$]$.

До проведення безпосередньо огляду перед слідчим постає завдання попереднього вивчення та аналізу наявної інформації, яка надійшла 3 повідомлення про вчинене кримінальне правопорушення, для того щоб розробити план проведення слідчої (розшукової) дії, визначити оптимальний склад слідчої групи, а також вирішити питання залучення кваліфікованого спеціаліста з певної галузі. 3 огляду на залучення слідчим певних фахівців, С. О. Тіщенкова зазначила, що також велику роль безпосередньо в момент огляду може відіграти кінолог з розшуковим собакою, допомога якого потрібна для затримання злочинної групи по «гарячих слідах» [7, с. 411].

Досліджуючи тактику проведення огляду місця події в провадженнях про злочини, вчинені організованою групою, В. М. Биков у своїх працях вказував, що головним чином слідчий повинен звертати увагу на сліди, що вказують на груповий характер злочину, зокрема: сліди рук або ніг, залишені різними особами; недопалки різних марок цигарок, різний прикус на знайдених недопалках; велика кількість використаного посуду, столових приладів; гільзи і кулі до різноманітних систем вогнепальної зброї або гільзи і кулі від патронів до зброї однієї системи, але випущені відповідно до висновку судово-балістичної експертизи з різних стволів; сліди крові, сперми, слини, випорожнень, що за висновками експертиз не належать одній людині; перенесення чи пересування великогабаритних або важких предметів, які неможливо пересунути або перенести самотужки; чималий обсяг викраденого; численні та різнохарактерні за механізмом утворення тілесні ушкодження [8, c. 26; 9, с. 41]. Для негайної організації розшуку злочинців і виявлення слідів за межами місця події встановлюються шляхи, яким організована група прибула до місця вчинення злочину, та шляхи відходу, на що можуть вказувати доріжка слідів взуття, напрямок відбитків слідів шин автотранспорту та ін.

Зрештою, в ході огляду місця події слідчий з'ясовує питання про: характер події, що мала місце; шляхи проникнення злочинців на місце і шляхи їх відходу; чисельність злочинців; час вчинення злочину; послідовність пересування злочинців на місці події, процес вчинення певних дій, контакту із навколишнім середовищем; знаряддя або засоби, які використовувались членами групи; мету злочинної діяльності; сукупність слідів, залишених на місці події; потенційних свідків, які могли бачити те, що відбувалося на місці події [10, с. 196]. Отримані відомості мають комплексний характер, а тому можуть використовуватись різнопланово, зокрема для здійснення розшуку підозрюваних, проведення допитів, пред'явлення для впізнання та інших слідчих (розшукових) дій. Треба погодитись 3 поглядами Т. В. Авер'янової, яка вказує, що отримана інформація є підгрунтям для подальшої організації розслідування, висування і перевірки криміналістичних версій $[11$, c. 576]. Серед обставин загального характеру, які можуть вказувати на вчинення злочину саме організованою групою, варто виділити такі: 1) вчинений злочин за характером та спрямованістю передбачає участь кількох осіб; 2) застосування цілого ряду прийомів, способів вчинення злочину, що вказує на своєрідний розподіл функцій між співучасниками; 3) велика кількість різних за характером залишених слідів. У такому разі про груповий характер злочину свідчать кількість столових приладів, недокурків цигарок різних марок і 


\section{Кримінальне право, кримінальний процес та криміналістика}

3 різною манерою гасіння, сліди взуття різних моделей, сліди застосування декількох знарядь злому тощо [12, с. 53].

Не менш важливим є проведення допитів підозрюваних. У такий спосіб, як зазначає--М. П. Яблоков, встановлюються відомості про тісні стосунки між учасниками групи, спільні ціннісні орієнтації, коло знайомих, лідера організованої групи, мету створення об'єднання, його структуру, обсяг злочинної діяльності та інші відомості, які вказують на згуртованість і змову членів групи [4, с. 136].

Під допитом розуміють слідчу (розшукову) дію, яка регулюється відповідно до ст.224 КПК України, змістом якої є одержання показань від особи, яка володіє відомостями, що мають значення для розслідування кримінального правопорушення. Для того, щоб допит був ефективним, слідчий повинен чітко усвідомлювати, яку інформацію і за допомогою яких прийомів чи засобів він має намір отримати. Під час допиту необхідним завданням є з'ясування обставин, існування яких виключає можливість нерозуміння особою членства в угрупованні, зокрема: чи проводилися зустрічі, сходки для планування злочинної діяльності, обговорення подальших сумісних дій, визначення злочинної спрямованості, визначення навичок та вмінь кожного з учасників тощо.

У межах проведення первинного допиту підозрюваних характерним $є$ те, що сторони мають протилежні інтереси і прагнуть до досягнення різних цілей в умовах інформаційної невизначеності. Водночас вони докладають зусилля для введення супротивника в оману і маскування своєї тактичної позиції, внаслідок чого формується конфліктна ситуація, зіткнувшись з чим, слідчий повинен наперед продумати відповідні тактичні прийоми, використовуючи методи «управління ситуацією» та можливі способи рефлексії. Як зазначають С. К. Пітерцев та Г. Г. Доспулов, 3 урахуванням особистості допитуваного, варто розробити стратегію допиту, передбачити можливі «ходи супротивника», лінію його поведінки й обрати тактичні прийоми, застосування яких виявиться найефективнішим [13, с. $27 ; 14$, с. 7].

У криміналістичних джерелах, до тактичних прийомів допиту в провадженнях, пов'язаних із зорганізованими групами, відносять: допит слабкої ланки; використання чинника несподіваності; непрямий допит; створення у допитуваного перебільшеного уявлення про обізнаність слідчого; допущення легенди; роздроблення сил і засобів протидіючої сторони шляхом розпалювання конфлікту [15, с. 519].

Найдоречніше проводити допит «слабкої ланки» організованої групи, яка в силу невдоволеності займаним положенням в групі, або через інші причини $є$ найбільш поступливим до співпраці з слідчим. Важливим засобом у цьому плані стає інститут угоди про визнання винуватості, який відповідно до ст.ст. 468, 469 КПК України полягає в повному та беззастережному визнанні підозрюваним чи обвинуваченим своєї винуватості та підтверджує згоду підозрюваного, обвинуваченого на призначення заздалегідь обумовленого зменшеного покарання, за умови викриття злочинної діяльності угрупування.

У разі наявності внутрішнього конфлікту в групі слідчий має можливість використати наявні протиріччя 3 метою подолання психологічної згуртованості членів злочинного угруповання. Якщо допитуваний буде мати суперечності щодо організації діяльності групи, він зможе надавати правдиві відомості про співучасників у зв'язку з особистою неприязню. Як вважає I. В. Куртинов, використання слідчим внутрішніх суперечностей між учасниками злочинної групи зумовить роз'єднання іï членів і створить можливість отримати правдиві відомості про роль кожного співучасника [16, с. 79]. У такому разі, головним завданням слідчого має бути контроль конфлікту в необхідному руслі. При цьому, на допиті підозрюваних акцентується увага не на безпосередній події злочину, а на моментах виявлення, створення і загострення конфліктів між співучасниками, їх причинах та інших обставинах створення і функціонування організованої злочинної групи.

У конфліктній ситуації для ефективного отримання достовірних показань використовують метод непрямого допиту, який полягає в постановці слідчим другорядних питань, які допитуваному видаються такими, що взагалі не відносяться до безпосереднього предмету допиту. При цьому більш дрібні та незначущі 
запитання повинні конкретизувати головну тему допиту та вирішувати головне питання, але фактично маскуючи мету допиту (наприклад, якщо виявлені відбитки пальців підозрюваного, то варто задавати такі питання, відповіді на які зрештою виключать можливість стверджувати, що відбитки залишені раніше або пізніше, але не в момент вчинення злочину).

Прийом допущення легенди надає підозрюваному можливість безперешкодно висловлювати свою вигадану версію подій. Отримавши неправдиві свідчення від допитуваного, необхідно спокійно зафіксувати їх у протоколі допиту, а після цього продемонструвати допитуваному хибність його позиції. Іноді у вільній розповіді допитуваний застосовує завчасно підготовлене неправдиве алібі, яке готувалося групою для протидії від викриття. У разі заяви про алібі підозрюваним, пропонується використати такий комплекс тактичних заходів: слідчий проводить допит заявника aлiбi iз застосуванням тактичних прийомів деталізації та уточнення показань. Отримана інформація про обставини алібі далі перевіряється під час допитів інших членів групи, свідків, потерпілого, інших осіб, котрі фігурували в алібі. Слідчий, формуючи попередній висновок про сутність алібі, може провести повторний допит суб'єкта алібі та інші слідчі (розшукові) дії з використанням системи тактичних прийомів, що спрямовані на викриття неправдивих показань [17, с. 39].

Серед загальних питань, які потребують встановлення під час допиту підозрюваного, є: хто, коли, за яких обставин запропонував вступити в угруповання; чому пропозиція надійшла саме допитуваному, що пов'язувало його 3 іншими членами угруповання; мотиви і мета вступу; якою є структура злочинного угруповання, функції й роль окремих учасників, хто виступав у ролі керівника; яку зброю і боєприпаси мали учасники, кому вони належать, коли придбані, де, ким, за яких обставин, де зберігалися; які транспортні засоби були в учасників угруповання, кому вони належали, яке джерело їх походження; де відбувалися зустрічі учасників, які правила конспірації дотримувалися; якими способами здійснювався зв'язок між членами; як розподілялося викрадене, де воно зберігалося, на які цілі використовувалося; яким чином здійснювався захист угруповання від діяльності правоохоронних органів [18, с. 12].

Особливого значення для розслідування кримінальних правопорушень, вчинених ОЗГ, набуває проведення обшуків, які, крім вилучення доказів за окремими епізодами злочинної діяльності, дозволять встановити факт узгодженості намірів і дій членів групи, і в такий спосіб підтвердити ії організованість. У криміналістичній літературі певним чином науковці намагалися типізовані предмети пошуку, характерні для проваджень про організовані злочини. Зокрема, В. С. Коновалова та В. Ю. Шепітько до таких предметів відносять: знаряддя злочину або предмети, спеціально призначені для здійснення протиправних дій (зброя, відмички, вибухові пристрої, підроблені печатки); різноманітні речі або цінності, здобуті злочинним шляхом (гроші, транспортні засоби або ж предмети безпосередньо викрадені злочинцями, отримані в результаті вимагання, шантажу, інших протиправних дій); предмети, які свідчать про подію злочину, вказують на можливість переховування осіб у конкретних місцях або на приховування певних предметів, що мають відношення до злочину (чорнові записи із планом дій, карти-схеми, записки, блокноти, особисті листи, записні книжки, фотознімки); предмети маскування (перуки, шапки, окуляри, маски, уніформа, наприклад, співробітників поліції, інша атрибутика, яка маскує зовнішність); засоби зв'язку та інші технічні прилади (прилади нічного бачення, електронні прилади для вимкнення сигналізації); документи, що містять відомості про знайомства і зв'язки членів групи [19, c. 14-16]. 3 урахуванням поширення новітніх технологій не можна нехтувати значимістю мобільних телефонів, планшетів, SIM-карт, накопичувачів для встановлення інформації різного характеру про користувача певним технічним засобом. Серед них найбільшого значення для розслідування мають мобільні телефони, які містять перелік контактів і номерів телефонів найближчих родичів і знайомих, а також є місцем зберігання фотографій, відеороликів, записів, нагадувань, відміток на календарі тощо. Встановлені на телефоні чи планшеті додатки дозволяють проаналізувати історію пошуку в мережі Інтернет, прослідку- 


\section{Кримінальне право, кримінальний процес та криміналістика}

вати відвідані веб-сайти, ознайомитися з листуванням співучасників через електронну пошту. Шляхом автоматичного фіксування на телефоні GPS можна визначати останні відвідані місця [20, с. 144].

У разі встановлення відомостей про декількох членів групи проводять групові обшуки, які в силу своєї несподіваності унеможливлюють вчинення дій, що спрямовані на знищення доказів або приховування майна. Груповий обшук передбачає проведення декількох обшуків у межах одного провадження у різних осіб, у різних місцях в один і той же час. Такий обшук завдяки ефекту раптовості зазвичай призводить до позитивних результатів. Предмети пошуку в ході групових обшуків залишаються незмінними, але значною мірою залежать від спеціалізації організованої групи. На цьому справедливо наголошує С. Ф. Денисюк, додаючи, що під час групових обшуків дії членів злочинного об'єднання стають незлагодженими, оскільки не залишається часу на розробку плану щодо зміни місць приховування доказів, що також дозволяе подолати опір підозрюваних [21, с. 226]. Разом 3 тим, із тактичних міркувань, обшуки можуть бути послідовними. При такому варіанті тактична вигода для слідства може полягати в: забезпеченні захисту осіб, що співпрацюють зі слідством, оскільки створюється уява, що інформація для подальших обшуків була отримана під час проведення першого; спонуканні осіб до переміщення та зміни місць приховування доказів, що створюе умови для їх затримання в цей момент (в такому випадку може бути застосована тактична операція «контрольована протидія розслідуванню»).

\section{Висновки}

Кількісні та якісні характеристики ОЗГ як особливого суб'єкта злочинної діяльності обумовлюють специфіку тактики проведення слідчих (розшукових) дій початкового етапу досудового розслідування у відповідних провадженнях, зокрема, огляду місця події, допиту підозрюваних, обшуку. Ця специфіка проявляється як у спрямованості слідчих (розшукових) дій та їх послідовності, так і в тактичних прийомах, що можуть бути застосовані при їх проведенні. Врахування наведених особливостей таких дій у слідчій практиці буде сприяти ефективності кримінально-процесуального доказування організованого характеру злочинної групи.

\section{入iтepaтyра}

1. Панов М. І., Шепітько В. Ю., Коновалова В. О. Настільна книга слідчого. 2-ге вид., перероб. і допов. Київ: Ін Юре, 2007. 728 с.

2. Топчій В. В. Планування розслідування злочинів, учинених організованими злочинними групами. Юридичний вісник, 2015. № 1 (34). С. 169-174.

3. Драпкин Л. Я. Проблемы расследования преступлений, совершаемых организованными сообществами. Криминалистика: учебник. Москва: Высшая школа, 1994. $708 \mathrm{c}$.

4. Яблоков Н. П. Расследование организованной преступной деятельности: практ. пособ. Москва: Юристь, 2002. 171 с.

5. Проценко М. В. Особливості розслідування злочинів, вчинених організованими групами, у криміналістичній методиці: дис. ... канд. юр. наук. Харків, 2008. 213 с.

6. Макаренко E. I., Негодченко О. В., Тертишник В. М. Огляд місця події: навч. посіб. Дніпропетровськ, 2001. 156 с.

7. Тіщенкова С. О. Особливості організації і тактики проведення огляду місця події. $\mathrm{Ha}$ уковий вісник ДДУВС, 2014. № 4. С. 409-413.

8. Быков В. М. Особенности расследования групповых пре ступлений. Ташкент: НИиРИО Ташк. ВШІ МВД СССР, 1980. 60 с.

9. Быков В. М. Преступная группа: криминалистические проблемы. Ташкент: Узбекистон, 1991. 143 с.

10. Кофанов А. В., Кобилянський О. А., Кузьмічов Я. В. Криміналістика: питання i відповіді: навч. посіб. Київ: Центр учбової літератури, 2011. 280 с.

11. Аверьянова Т. В., Белкин Р. С., Корухов Ю. Г., Российская Е. Р. Криминалистика. Учебник для вузов. Москва: НОРМА, 2000. 990 с.

12. Глазырин Ф. В. Изучение личности обвиняемого и тактика следственных действий: Учебное пособие. Свердловск: СЮИ, 1973. 156 с.

13. Питерцев С. К., Степанов А. А. Тактика допроса. Санкт-Петерберг: Питер, 2001. 160 с.

14. Доспулов Г. Г. Психология допроса на предварительном следствии. Москва: Юрид. лит., 1976, с. 112. 


\begin{tabular}{|c|}
\hline 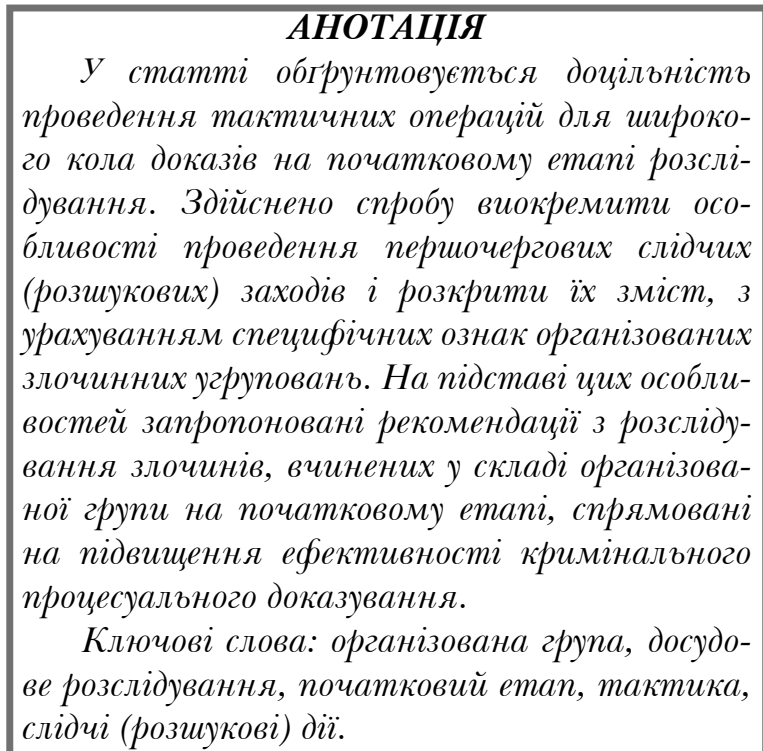 \\
\hline
\end{tabular}

15. Гула $\mathcal{~}$. Ф. Використання тактичних прийомів у розслідуванні злочинів, вчинених організованими злочинними угрупованнями. Вісник Національного університету «Һвівсъка політехніка», 2016. № 845. С. 515-521.

16. Коловоротный А. А., Куртынов И. В. Особенности выявления организатора и участников преступного сообщества при расследовании совершенных ими преступлений. Вестник Волгоградской академии МВД России. Волгоград, 2013. С. 78-82

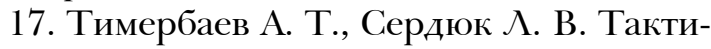
ка проверки заявления об алиби на предварительном следствии: учеб. пособ. Хабаровск: Хабар. высш. шк. МВД СССР, 1987. 62 с.

18. Бердникова О. П. Тактические приемы первоначального допроса активного участника организованной группы специализирующейся на совершении разбойных нападений. Полицейская и следственная деятельность. Москва: НБ-Медиа, 2017. С. 10-17.

19. Коновалова В. Е., Шепитько В.Ю. Обыск: тактика и психология. Харьков: Гриф, 1997. 80 c.

20. Осіпов Я. В. Алгоритм пошуку підозрюваних за мобільними телефонами. Актуальні проблеми сучасной науки і правоохоронної діяльності. Харків, 2018. №25. С. 144.

21. Денисюк С.Ф. Проблеми тактики обшуку в сучасних умовах боротьби з організованою злочинністю. Вісник Академії правових наук України. № 1. Київ, 1999. С. 224-227.
Kisko Artem Ivanovich

postgraduate

(Donetsk Law Institute, MIA of Ukraine)

INVESTIGATIVE (SEARCH) ACTIONS

AT THE INITIAL STAGE OF INVESTIGA-

TION CRIMES COMMITTED AS PART OF AN ORGANIZED GROUP

The modern reform of economic and political life in Ukraine requires an intensification of the fight against organized crime. But there is still disagreement in the legal literature regarding determination of the most appropriate tactics for conducting pretrial investigation of crimes committed by an organized group. This problem is associated with specific forensic signs of criminal associations, which must be established in each specific criminal proceeding on group crimes. In particular, group crimes are characterized by the presence of a large number of accomplices, the existence of several episodes of criminal activity, the formation of a wide range of criminalistics versions, and other. These factors greatly complicate and inhibit the process of pretrial investigation. Considering this, the execution of investigative (search) actions has its own characteristics. The execution of such measures is intended to prove the fact of the stability of the group, as well as other signs, thanks to which it can be concluded that the criminal organized group actually exists. Neglecting the criminalistics features of criminal groups will not allow to quickly and efficiently solving a criminal case. To solve such problems, it was determined the feasibility of tactical operations to obtain a wide range of evidence at the initial stage of the investigation. An attempt has been made to highlight the features of the implementation of expedient priority investigative (search) measures and determine their essence. The importance of conducting tactical operations to increase the effectiveness of criminal procedural evidence at the initial stage is determined. Based on these features, the article contains recommendations for investigating crimes committed as part of an organized group, given their essential features.

Key words: organized group, pretrial investigation, initial stage, tactics, investigative (search) actions. 